\title{
Factors Affecting Volunteer Rotation in Independent Audit Firms
}

\author{
Erdem KÜRKL ̈Ü \\ Doctor \\ Department of Transportation \\ Osmaniye Korkut Ata University \\ Osmaniye, Turkey \\ Zeynep TÜRK \\ Professor \\ Department of Business Administration \\ Osmaniye Korkut Ata University \\ Osmaniye, Turkey
}

\begin{abstract}
In this study, it is investigated why public companies in Turkey changed the independent audit firms as a result of voluntary rotation and which factors have been effective on these changes. The data set of the study consists of the annual activity reports, financial statements, audit reports and company news of 1169 companies belonging to 8 different sectors that were traded continuously on the Borsa Istanbul (BIST) index between 2011-2017.Research hypotheses were established by using variables like previous audit opinion, size of the audit company, the financial condition of the business, size of the business, change in business management, business combination, independence of business management and the impact of lenders that are commonly used in the literature and accessible on the sample data in Turkey. Binary logistic regression analysis was used in data analysis.
\end{abstract}

Keywords: Independent audit firms, voluntary rotation.

\section{Introduction}

In today's economies, which are getting more and more complex with each passing day, the information required to be able to make decisions in accordance with different purposes should be valid and reliable (Sayg1l, 2011:3897). This need for reliable financial information has shaped the independent audit establishment, with the effect of legal regulations, and has brought to us independent audit firms, one of the most important audit mechanisms. Due to this importance, many studies have been conducted in the world that question the independence, quality, and effectiveness of independent audit firms that issue independent audit reports. Some of these studies also provide important clues about why publicly traded companies in countries such as the USA, UK, Iran, China, Belgium, and Malaysia have changed their independent audit firms. In these studies, it was seen that the reason for changing the independent audit firms of the client businesses was classified into two categories: mandatory rotation, which they had to change as a result of legal regulations, and voluntary rotation, which they changed voluntarily (for various reasons).

Regardless of the reasons that push client businesses to change an independent audit firm, sharing these changes with the public is a requirement of accountability and transparency. Therefore, companies registered with SEC in the USA are required to report any auditor/audit firm change since 1971 on the 8-K form (Kızılgöl and İşü̈den, 2007:6). The aforementioned form includes information on the previous audit reports, explanations on why client companies have changed audit firms, and opinions on other important issues, such as disputes with previous auditors (SEC Matters Related to Accountants and Financial Statements, Section 4). In this way, both the partners of the customer business and the public are informed about the activities and results of the customer business. This statement is not unilateral, and the independent audit firms also express their opinions or objections on the same subject in detail (Kızılgöl and İşüden, 2007:6).

In this sense, this issue, which is important in determining what kind of disagreements there are between the client enterprise and the independent audit company, necessitates the investigation of the determinants of the audit firm change.

Therefore, in this study, the reason for the change was tried to be explained by using variables such as the previous audit opinion, the size of the audit company, the financial status of the business, the size of the business, the change in business management, the business combination, the independence of the business management and the effect of the lenders, which are considered to affect independent audit firm changes as a result of the voluntary rotation, and which are frequently used in the literature. 


\section{Literature}

Academic studies conducted in various countries about the reasons that push client businesses to independent audit firm change have been examined and the factors and study results that have an effect on independent audit firm change as a result of voluntary rotation have been found as follows:

Vanstraelen (2000) reviewed the effect of positive auditor opinion on both audit firm change and bankruptcy of client business. As a result of the study performed on 784 companies in Belgium, it was found that the audit firm change was related to the positive audit opinion. Lennox (2000) analyzed the relationship between auditor opinion type and audit firm change. 949 British companies were included in the research and a total of 5441 observations were examined. The probit analysis method was applied. As a result of the study, it has been revealed that client businesses choose audit firms according to the type of audit opinion they have given. Woo and Koh (2001) analyzed 16 variables that caused audit firm change on 108 companies traded on the Singapore stock exchange in the period 1986-1995. A logit analysis has been used. As a result of the study, factors such as independent audit opinion type, audit quality, changes in management, profit planning, company growth, debt level, company merger, business ownership distribution emerged as the most important factors affecting audit firm change. It has been determined that companies that work with small audit firms, whose management structure changes frequently and have high financial debt, are more likely to change audit firms.

Carcello and Neal (2003) examined the relationship between audit committee characteristics and audit firm change. The audit reports submitted by six large audit firms between 1988-1999 and the number of layoffs of audit firms were analyzed. As a result of the research, it was found that if the audit committee can speak authoritatively about the company, the probability of the client companies to change the audit firm increases.

Branson and Breesch (2004) surveyed companies operating in Belgium to examine audit firm changes. As a result of the study, it was concluded that when the parent company decided to change the audit company, the affiliated companies also comply. Asthana et al. (2004) found that the main reason behind the audit firm change was audit fees. Especially in small companies, it has been determined that the change of audit firm due to higher audit fees.

Hudaib and Cooke (2005) conducted a study analyzing the effects of business management change and financial difficulties on audit firm change. In the study, control variables such as audit fees, long-term debts, firm size, audit firm type, and auditor opinion were used. Sample selection was obtained by applying logistic regression analysis of the data of 297 companies traded in the UK stock exchange. The findings indicate that businesses tend to change audit firms after receiving an audit report other than positive opinions. Besides, it has been identified that businesses that receive reports without a positive opinion, financial failure, and change CEOs make more changes in audit firms than businesses that do not have financial difficulties and do not change CEOs.

Sriram (2006) examined certain customer characteristics of a group of companies in his study and tried to determine whether some of these characteristics are more closely related to the change of the audit company. The results indicate that businesses with negative opinions, small-scale businesses, and businesses that are traded in the over-the-counter market change audit firms more. It has been observed that companies audited by larger audit firms are less likely to change audit firms.

Nasser et al. (2006) examined the relationship between the same client business and the working time and audit firm change. The factors affecting the relationship between them were calculated using the logistic regression method in a sample of 297 companies traded in the Malaysian Stock Exchange in the 1990-2000 period. According to the results of the research, it has shown that the change in total assets, financial risk, and company size are significantly associated with the audit firm changes. Besides, it was found that firm growth, change in profit and equity structure are not significantly related to audit firm change. Furthermore, companies audited by a large audit firm were less likely to change than companies audited by smaller audit firms.

Boon et al. (2007) examined audit firm changes in 125 companies operating in Australia between 1993 and 2002. The data has been obtained from the Australian local government and annual reports. As a result, it has been determined that the change of audit firm is more intense in businesses that operate on a small scale. In the research conducted by Ming (2007), the relationship between company management mechanism and audit firm preference was investigated. The sample of the study consists of 1,387 companies listed on the Shanghai and Shenzhen Stock Exchanges between 2001-2004. The data were retrieved from the CSMA Financial Database. As a result of the research, it was found that there is a significant relationship between the management change in the company and the audit firm change.

Bagherpour (2007) examined the relationship between business management and audit firm change in his research conducted in Iran. The data has been obtained by accessing the financial statements of 784 businesses between 1999-2003. As a result of the research, no relationship has been found between the change of audit firm and business management. 
Wan Mohamed et al. (2007) conducted a study in Malaysia on the characteristics of businesses that changed the audit company. In the study, public companies that changed the audit firm between 1996-2004 are addressed. The data were obtained from the annual activity reports posted on the companies' internet addresses. The findings showed that the most important factor in the audit firm change is the audit fee.

Ettredge et al. (2007) investigated the relationship between audit fees and audit firm changes. In the study, the possibility of changing an audit firm in companies that pay a high amount of audit fees was investigated. The logistic regression method was applied to the data of 4516 companies that did not change audit firms and 428 companies that did change audit firms in the USA in the 2001-2003 period. As a result of the study, it was found that companies that pay high audit fees are more likely to change audit firms. Besides, it has been observed that companies, which change audit firms and work with an audit firm other than the four majors, pay fewer audit fees in the following year than companies that do not change the audit company.

Knechel et al. (2007), investigated the reaction of investors to the change of audit firm between the periods of 2000-2003, based on 159 experienced audit firms and 159 audit firms without experience. As a result of the study, it is understood that the investors are willing to the companies working with an experienced audit company.

Dhaliwal et al. (2007) examined the relationship between the financial condition of the client business and the change of audit company. In the study, they argued that the management of the company with poor financial performance would prefer an audit firm that shows the financial condition of the enterprise better. However, they stated that the audit firm would lose its reputation due to such a choice. In this context, it has been suggested that the dispute that will arise when the audit firm does not allow the accounting practice that increases or inflates the profit of the company, can be resolved with the decision of the client business to change the audit company.

Chen et al. (2008) conducted an experimental study to test the relationship between financial failure and audit firm change. As a result of the study, it was found that there is a positive relationship between financial failure and audit firm change.

Ismail et al. (2008), in their study, used 3 categories to detect audit firm change: customer contract environment, customer company reputation, and auditor efficiency. As a result of the study, it has been revealed that the most important determinants of the audit firm change in Malaysia are the debt level, growth rate, financing activities, the duration of its participation in the audit and the audit fee.

In the study conducted by Calderon and Ofobike (2008), the factors that best predicted audit firm changes in the USA were examined. In the study, 6,510 audit firm changes were examined. The data were analyzed using classification and regression trees (CART). As a result of the research, it was revealed that the audit fee was not effective in the decision to change the audit company.

Jackson et al. (2008) examined the audit firm changes in Australia between 1995 and 2003 and 772 audit firm changes were determined. The data were obtained from the database "Crawsell Who Audit Australia". Findings have shown that the length of the audit firms' tenure increased the quality of the audit with the tendency to give more successful auditor opinions. Therefore, it has been stated that there has been a decrease in audit firm changes in Australia.

Knechel et al. (2008) found that, as a result of the pressure created by financial institutions (lenders), companies that switch to four major audit firms are given lower loan rates. Bagherpour et al. (2009) investigated the extent to which increasing auditor competition, changes in company objectives, and operating costs increased audit firm change in Iran. According to the results of the research, it has been determined that factors such as audit quality, change in management, and audit fees are effective on audit firm change.

Lin and Liu (2010) conducted a study on the relationship between companies' management mechanisms in China and their decision to change audit firms between 2001-2004. The audit firm analyzed the changes by the logistic regression method. In the study, two types of audit firm changes were identified, namely large audit firms and small audit firms. As a variable, three variables were used: ownership density in the company (the share of the largest shareholder in the company), the efficiency of the supervisory board, and the board of directors. The findings revealed that companies with weak company management mechanisms tend to switch to smaller audit firms. Besides, it has been found that businesses with a high percentage of shareholder ownership make the audit firm change towards smaller audit firms. Again, in the study, why businesses listed on the Hong Kong stock exchange prefer Chinese auditors, and the response of the market to the audit firm change was measured. It has been found that businesses that have switched to Chinese auditors are less likely to be audited by the Major Four audit firms and export less than total sales. Besides, the Hong Kong market has been found to react negatively to businesses that prefer Chinese auditors. 
Chadegani et al. (2011) examined 182 companies for the period 2003-2007 to determine the audit firm changes of companies listed on the Iran Tehran Stock Exchange. The data have been accessed through company financial statements and meeting minutes. In the study, factors such as changes in management, financial failure, negative audit report, audit fees, customer size (business size), audit firm size were analyzed by logistic regression method. As a result of the research, only the variable of audit firm size was found to be significantly associated with audit firm change among these factors. Besides, in the study, it was mentioned that large companies will need to work with larger audit firms due to their more complex activity structure.

Kwak et al. (2011) estimated the financial failure variables and the changes in the independent audit company. In the study, the data mining method was applied to 790 companies that did change audit firms and 1132 firms that did not change audit firms in the USA for the 2007-2008 period. In companies that change the audit company, It has been observed that the variables of Net Working Capital/Total Assets, Short-Term Debts/Current Assets, Dividend Payment, Profit Before Interest and Tax/Total Assets are significantly different from companies that do not change the audit firms.

In a study conducted in Canada by Fontaine and Letaifa (2012), the reasons between the quality of the audit service and the changing audit firm were examined. As a result of the study, it was revealed that economic issues, especially the audit fee, were the most important reason for the change of audit company.

Nazri et al. (2012) conducted a study to examine the characteristics of businesses that changed audit firms among publicly traded companies in Malaysia. The findings of the survey studies were analyzed using the logistic regression method. 400 companies in Malaysia were studied. The data were obtained from the companies' website and the Malaysian Companies Commission. Variables consist of elements such as a change in management, negative audit report, business size, audit quality, financial structure, and audit fee. As a result of the study, it was found that the increase in the level of indebtedness increases the probability of changing the audit firm of the client business, and factors such as a change in management and business size have an effect on the change of audit company. Besides, it was concluded that large firms tend to switch audit firms more frequently.

Black et al. (2012) used the logistic regression method to examine the audit firm change. Financial ratios (revolving fund/total assets, return on assets, stock market value/total debt book value, sales/total assets) of companies that changed and did not change the audit firm were examined. It was observed that $92 \%$ of the companies that changed the audit firm did not have a good financial performance.

Huang and Scholz (2012) tried to explain the relationship between the financial performance of companies and audit firm change. In their studies, they found that fraudulent financial data (turning profit into a loss, etc.) significantly increased the resignation of the auditor. Besides, it has been observed that fraudulent companies have tried to deal with larger audit firms after resigning from the auditors.

Weiner (2012) examined the main reasons behind changing the audit firm in his study. It found that in many cases, their company decided to switch to one of the four major audit firms, in some cases continuing with their companies' former auditor. In the study, it was found that large companies working with one of the four big audit firms made the audit firm change with one of the four big audit firms and that the companies that agreed with a small audit firm wanted to switch to a major audit company.

Fontaine and Letaifa (2012) found a positive correlation between audit firm change and auditor fees in their study in the Belgian market for the period 1989-1997. Eldridge et al. (2012) tried to estimate the audit firm change in the USA in the 2007-2008 period based on 13 financial failure variables. Discriminant analysis was used as a method. As a result of the research, the variables that affect the estimation of audit firm changes; profit share, loss, undistributed profit/total assets, profit before interest, and tax/total assets.

Suyono et al. (2013) analyzed the relationship between the financial status of manufacturing companies listed on the Indonesian Stock Exchange and the change of the audit company. The survey method obtained by distributing questionnaires was used. 45 out of 136 businesses returned. As a result of the findings, a significant and positive relationship has emerged between the financial status of the client and the change of audit company. The most important indicators; financial performance, competition among audit firms, and audit quality. According to the results, the factors of auditor fee and audit firm size were not significant.

Black et al. (2013) applied regression and discriminant analysis to the companies, which traded in the Greece stock exchange and changed the audit firms, with the help of 4 financial ratios (Net Working Capital/Total Assets, Return on Assets, Equity/Total Debt, Sales/Total Assets) determined by Altman. As a result of the research, it was seen that these four ratios were effective in explaining the audit firm change. Besides, it was determined that the logistic regression method was successful in classifying audit firm change correctly $(92.3 \%)$, while discriminant analysis (47.6\%). 
Han (2013) focused on the reasons for company change in the audit for public companies in the Kazakhstan Stock Exchange. As a result of the study, the reasons for the client business to change the audit firm were determined as the quality of the audit, and the reputation of the audit company.

Yaman et al. (2013) analyzed the reasons for the change of audit firm of public companies in Shanghai and Shenzhen stock exchange within the framework of company management elements. By determining 15 company management elements, they used statistical tests and logistic regression analysis method to reveal how the audit affected the company change. The results showed that the share of the largest shareholder representing the management, the independent directors (members) of the company, and the board meetings were associated with the audit firm change.

Nyakuwanika (2014) investigated the underlying reasons for companies in Zimbabwe changing audit firms. In the study, variables such as negative opinion, non-audit services, audit quality, CEO change, and company size were examined with the audit firm change. The researcher used questionnaires as the primary data collection tool and various publications to obtain secondary data. The results of the study showed that auditor fees, non-audit services, audit quality, management change, and business size play an important role in companies moving from one audit firm to another.

Cheng Won Theng et al. (2014) conducted a study of publicly traded companies in Malaysia. Findings of the study; demonstrate that changes in risk level, management staff, and audit fees have a significant relationship with audit firm change. The study also showed that the complexity of business activities was not significantly related to audit firm change.

Al-Kouryet al. (2015) conducted a study on auditor independence and audit firm change in Jordan. The results of this study revealed that there is a significant relationship between auditor independence, the relationship between the auditor and the client, and audit firm change. It has been observed that as the level of relationship between the auditor and the client increases, the companies continue to work with the same audit company.

Yaşar (2016) analyzed the data of 160 companies in the BIST Industrial Enterprises category between 2012 and 2015. As a result of the research, it was determined that the variables of the previous audit opinion and the size of the independent audit firm among the eight factors that affect the independent audit firm change are significant.

\section{Data and Method}

In this study, in which the factors affecting the changes in voluntary audit firm rotation of open public companies were analyzed in the 2011-2017 period in Turkey, a total of 1169 (167 company x 7 years) corporate data due to eight different sectors are considered.

Table 1. Descriptive Statistics of the Sectoral Distribution

\begin{tabular}{lll}
\hline The Sectors & $\begin{array}{l}\text { Number } \\
\text { Companies }(\mathbf{N})\end{array}$ & $\begin{array}{l}\text { of } \\
(\boldsymbol{\%})\end{array}$ \\
\hline Manufacturing Industry & 115 & 69 \\
\hline Wholesale and Retail Trade, Hotels and Restaurants & 20 & 12 \\
\hline Technology and Informatics & 13 & 7.7 \\
\hline Transport, Communication and Storage & 6 & 3.5 \\
\hline Electricity, Gas and Water & 5 & 3.3 \\
\hline Construction and Public Works & 4 & 2.3 \\
\hline Mining & 3 & 1.7 \\
\hline Education, Health, Sports and Other Social Services & 1 & 0.5 \\
\hline Total* & 167 & 100 \\
\hline
\end{tabular}

Source: Prepared from official websites of www.kap.gov.tr

* Number of companies hitting each year

The companies in Istanbul Stock Exchange (BIST) Index operating in the field of mining, manufacturing, electricity, gas and water, construction and public works, wholesale and retail trade, hotel and restaurant, transportation, communication and storage, technology and informatics, education, health, sports and other social services were sampled and their annual activity reports, financial statements, company news and independent audit reports were analyzed. The companies, of which existence ceased due to circumstances of activity interruption, bankruptcy, etc. between 2011-2017 were excluded from the sample. Thus, data of 167 companies were analyzed for each year. 
Banks, factoring companies, financial leasing companies, investment trusts are excluded from the study due to the differences in their fields of activity and financial statement formats, as well as the fact that their asset structures are mostly cash and cash equivalents. In the relevant years, companies whose reason for independent audit firm change was due to mandatory rotation and companies whose change was due to voluntary rotation were separated.

Table 2. Descriptive Information Regarding Sample Selection

\begin{tabular}{lllllllll}
\hline Sample Selection & $\mathbf{2 0 1 1}$ & $\mathbf{2 0 1 2}$ & $\mathbf{2 0 1 3}$ & $\mathbf{2 0 1 4}$ & $\mathbf{2 0 1 5}$ & $\mathbf{2 0 1 6}$ & $\mathbf{2 0 1 7}$ & Total \\
\hline $\begin{array}{l}\text { Number of Companies } \\
\text { Examined in the }\end{array}$ & & 167 & 167 & 167 & 167 & 167 & 167 & 1169 \\
Research & & & & & & & & \\
\hline $\begin{array}{l}\text { Number of Companies } \\
\text { Changing audit firms }\end{array}$ & 19 & 23 & 60 & 37 & 26 & 50 & 72 & 287 \\
\hline $\begin{array}{l}\text { Number of Companies } \\
\text { That Have Not Changed } \\
\text { audit firms }\end{array}$ & 148 & 144 & 107 & 130 & 141 & 117 & 95 & 882 \\
\hline $\begin{array}{l}\text { Mandatory Rotation } \\
\text { Result audit firm change }\end{array}$ & & 3 & 31 & 5 & 7 & 9 & 52 & 109 \\
$\begin{array}{l}\text { Voluntary Rotation } \\
\text { Result Audit Firm } \\
\text { Change }\end{array}$ & 20 & 29 & 32 & 19 & 41 & 23 & 178 \\
\hline
\end{tabular}

With the Communique on Independent Auditing Standards in the Capital Markets (Series: X, No: 22), looking back to seven years from 2010; It is stipulated that companies that have been audited by the same independent audit firm seven times in a row cannot make an audit contract with the same independent audit firm for the eighth time.

With the revised Turkish Commercial Code in 2011, companies that were understood to have been audited by the same independent audit firm seven times in a row, regardless of being in a row, within ten years, retrospectively from the current financial year, required the mandatory change of audit firms. The implementation of this regulation started in 2013. Since the study includes both legal regulations, companies that undergo mandatory rotation were determined by taking this situation into account.

In the analysis, data analysis was carried out with the SPSS program, and variables were analyzed by binary logistic regression analysis using the "enter" method. Variables are identified as previous audit opinion (PAO), size of audit firm (SAF), the financial condition of the company (FCC), size of business (SB), change of chairman (CC), business merge (BM), independence of business management (IBM) and effect of lenders (EL). The model of the study was generated as follows such as in studies performed in the literature (Ming, 2007, Dhaliwal et al., 2007, Landsman et al., 2009, Lin and Liu, 2010, Eshagniya and Salehi, 2017):

$I A F C_{i t}=\beta_{o}+\beta_{1} P A O_{i t-1}+\beta_{2} F C C_{i t-1}+\beta_{3} S B_{i t-1}+\beta_{4} S A F_{i t-1}+\beta_{5} C C_{i t-1}+\beta_{6} B M_{i t-1}+\beta_{7} I B M_{i t-1}+\beta_{8} E L_{i t-1}+\varepsilon_{i t}$

Table 3. Variables and Their Definitions

\section{Dependent Variable}

$I A F C=$ for independent audit firm change as a result of voluntary rotation; 1 other; 0

Independent Variables

$P A O=$ If the previous audit opinion is positive, 1 other; 0

$F C C=$ for financially unsuccessful companies; 1 other; 0 (Altman Z Score Model was used.)

$S B=$ natural logarithm of total assets (total assets): $\ln (T A)$

$S A F=$ for companies audited by four big audit firms; 1 other; 0

$C C=$ for the change of $C E O$ (chairman of the board); 1 other; 0

$B M=$ if there is a business merge; 1 other; 0

$I B M=$ percentage of independent members on the board of directors of the enterprise

$E L=$ Long Term Liabilities/Proportional change of Total Assets compared to the previous year $\left(\mathrm{LTL}_{\mathrm{t}} / \mathrm{TA}_{\mathrm{t}}\right)$ -

$\left(\mathrm{LTL}_{\mathrm{t}-1} / \mathrm{TA}_{\mathrm{t}-1}\right)$

$i=$ client business

$t=$ current year

Although the application part of the study was carried out between 2011 and 2017, the data of the past (2003-2010) were also used, since the variables of the study also required data from the previous year. Current year, in which the audit firm change took place, is defined as " $t$ ", and the data, related to the relevant independent variables were found in the other studies in the literature (Dhaliwal et al., 2007, Landsman et al., 2009, Eshagniya and Salehi, 2018)as " $t-1$ ", which were calculated considering the period. By calculating the rotation periods of the mandatory 
audit firm, 2003 has been determined as the starting year to determine the relevant companies (to examine the backward periods). The null hypotheses for the variables were formed as follows.

Table 4. Hypotheses of the Research

\begin{tabular}{ll}
\hline $\begin{array}{l}\text { Independent } \\
\text { Variables } \\
\text { Symbol }\end{array}$ & Null Hypotheses \\
\hline PAO & $H_{0}:$ The previous audit opinion does not affect the independent audit firm change. \\
SAF & $H_{0}:$ The size of the audit firm does not affect the independent audit firm change. \\
SB & $H_{0}:$ Size of business does not affect independent audit firm change. \\
FCC & $H_{0}:$ Business Financial failure does not affect independent audit firm change. \\
BM & $H_{0}:$ Business merge does not affect independent audit firm change. \\
CC & $H_{0}:$ Change of Chairman $($ CEO) does not affect independent audit firm change. \\
IBM & $H_{0}:$ The independence of business management does not affect the independent audit \\
& firm change. \\
EL & $H_{0}:$ The effect of lenders does not affect independent audit firm change. \\
\hline
\end{tabular}

\section{Empirical Findings}

Table 5 presents the correlation matrix between independent variables. When the table is examined, since the correlation between independent variables is generally less than 0.2 , there is no multiple linear connection problem.

Table 5. Correlation Matrix Between Independent Variables

\begin{tabular}{llllllllll}
\hline $\mathrm{N}: 356$ & & SAF & PAO & SB & FCC & CC & BM & IBM & EL \\
\hline SAF & Spearman & 1 & -.017 & -.036 & -.037 & .054 & .094 & -.028 & -.070 \\
& Significance & & .749 & .805 & .489 & .313 & .076 & .616 & .184 \\
PAO & Spearman & -.017 & 1 & -.063 & -.045 & .092 & -.068 & .078 & .056 \\
& Significance & .749 & & .237 & .393 & .083 & .203 & .144 & .292 \\
SB & Pearson & -.036 & -.066 & 1 & .030 & -.074 & .077 & -.048 & -.074 \\
& Significance & .495 & .216 & & .576 & .164 & .148 & .366 & .163 \\
$\mathrm{FCC}$ & Spearman & -.037 & -.045 & -.017 & 1 & .033 & .058 & -.022 & -.012 \\
& Significance & .489 & .393 & .754 & & .535 & .271 & .677 & .823 \\
$\mathrm{CC}$ & Spearman & .054 & .092 & -.043 & .033 & 1 & -.052 & -.065 & -.015 \\
& Significance & .313 & .083 & .417 & .535 & & .327 & .224 & .781 \\
$\mathrm{BM}$ & Spearman & .094 & -.068 & .113 & .058 & -.052 & 1 & -.055 & -.032 \\
& Significance & .076 & .203 & .033 & .271 & .327 & & .298 & .550 \\
$\mathrm{IBM}$ & Pearson & -.028 & .068 & -.048 & .022 & -.003 & -.040 & 1 & .103 \\
& Significance & .595 & .199 & .366 & .673 & .948 & .453 & & .051 \\
$\mathrm{EL}$ & Pearson & -.070 & .079 & -.074 & -.001 & -.028 & -.022 & -.066 & 1 \\
& Significance & .188 & .138 & .163 & .984 & .604 & .682 & .051 & \\
\hline
\end{tabular}

Note: Pearson correlation coefficients in continuous variables (SB, IBM, EL) and Spearman-Rank correlation coefficients in categorical variables (SAF, PAO, FCC, CC, BM) are presented.

Table 6 shows the coefficient estimates, standard errors, Wald test results and Exp (B) values for the variables in the logit model.

Table 6. Binary Logistics (Enter Method) Regression Results

\begin{tabular}{llllllll}
\hline & & \multicolumn{3}{l}{ Standard } & & & \\
& & $\mathrm{B}$ & Error & Wald & df & Significance & Exp (B) \\
\hline Step 1 $^{\text {a }}$ & SAF & -.734 & .241 & 9.317 & 1 & $.002^{* * * *}$ & 2.084 \\
& PAO & .618 & .233 & 7.017 & 1 & $.008^{* * *}$ & .539 \\
& SB & .047 & .063 & .550 & 1 & .458 & 1.048 \\
& FCC & 1.491 & .287 & 17.071 & 1 & $.000^{* * * *}$ & .225 \\
& CC & -.284 & .488 & .338 & 1 & .561 & .753 \\
& BM & .126 & .392 & .104 & 1 & .748 & 1.135 \\
& IBM & .708 & .728 & .168 & 1 & .682 & 2.029 \\
& EL & 1.706 & .570 & 6.488 & 1 & $.011^{* *}$ & 4.509 \\
& Constant & 1.239 & .516 & 6.025 & 1 & $.086^{*}$ & .777 \\
\hline
\end{tabular}


${ }^{a}$ Variables included in the analysis in Step 1: SAF, PAO, SB, FCC, CC, BM, IBM, EL.

$* * *, * *$ and $*$ show significance at $1 \%, 5 \%$ and $10 \%$ significance level, respectively.

Accordingly in the model, while the variables of SB, CC, BM, IBM were found to be statistically insignificant (the aforementioned factors $H_{0}$ supports the hypothesis), while the variables of SAF, PAO, FCC and EL were found to be significant.If the significance of the variables is listed at the level of significance; The variables of PAO (previous audit opinion), size of audit firm (SAF) and financial condition of the company (FCC) were significant at 0.01 level of significance, while EL (effect of lenders) variable was significant at 0.05 significance level.

The negative sign of the variable SAF (size of audit firm) indicates that the probability of public companies audited, except for the four major audit firms, to make an audit firm change is higher than others. This supportive situation reflects previous studies in the literature (Healy and Lys 1986, Sriram, 1990, Woo and Koh, 2001, Nasser et al., 2006, Knechel et al., 2007, Lin and Liu, 2010, Chedegani et al., 2011, Nazri et al., 2012, Weiner, 2012, Huang and Scholz, 2012, Yaşar, 2016).

This result is interpreted as the reason why public companies audited by audit firms other than four major audit firms to change audit firms more frequently, seek better audit service and increase the reliability of investors to the business.

When the results of the variable PAO (previous audit opinion) were examined, it was seen that the value of the variable was positive and significant at $1 \%$ significance level. This situation points out in the literature that when public enterprises receive an audit report other than a positive opinion (negative, conditional, refraining from expressing an opinion), they may go to opinion shopping to get a positive report and change the audit firm. Previous study results also found results that support this situation (Craswell, 1988, Citron and Tafler, 1992, Vanstraelen, 2000, Aguilar and Barbadillo 2003, Hudaib and Cooke, 2005, Chadegani et al., 2011, Yaşar, 2016).

The variable FCC (financial condition of the company) is positively signed and significant at the $1 \%$ significance level. This result, which is consistent with previous study results (Menon and Schewartz, 1985, Haskins and Williams, 1990, Hudaib and Cooke, 2005, Hamilton et al., 2008), is expressed as the belief that in cases where public companies do not perform well financially, they may be willing to work with an audit firm that demands a lower audit fee and that changing the existing audit firm can be the solution to prevent financial adverse situations.

When the results of the variable EL (effect of lenders) were examined, it was seen that the value of the variable was positive and significant at the 5\% significance level. Such a result is interpreted in the literature as the deterioration of the financial structure of the company in parallel with the increase in the borrowing level in the long term, that the firm can be financed speculatively, the safety margin of the firm will narrow in terms of lenders and the financial institutions that provide loans to the business can speak authoritatively over the business. Previous studies (Tauringana and Clarke, 2000, Carey et al. 2000, Woo and Koh, 2001; Knechel et al. 2008, Minnis, 2011) this situation is explained as follows: lending brokers, creditors, and various financial institutions press the business to provide reliable financial statements to collect loans from the business promptly. Thus, the company, which is under the pressure of lending institutions, tends to change the existing audit firm to obtain a positive audit opinion to restore the atmosphere of trust. Besides, if we consider the EL and FCC variables together, the data for both variables support the idea that companies believe that changing the existing audit firm can be the solution when their financial situation deteriorates or when the level of debt increases.

In summary, in the model, it was seen that the variables of SB, CC, BM and IBM did not have a statistically significant effect. While this result supported some study results (Chow and Rice, 1982, Schwartz and Menon, 1985, Craswell, 1988, Krishan et al., 1996, Woo and Koh, 2001, Ettredge et al., 2007, Knechel et al., 2007, Chadegani et al., 2011, Cheng Won Theng et al., 2014, Yaşar, 2016), it differed with some study results (Bedingfield and Loeb, 1974, Firth, 1999, O' Sullivan, 2000, Beasley and Petroni, 2001, Salleh et al., 2006, Boon et al., 2007). Therefore, according to the results of the enter method, the variables of business size, independence of business management, change of chairman (CEO) and business merge variables do not affect the independent audit firm change as a result of the voluntary rotation in companies listed in the BIST index.In this case, according to the enter method result,it points out that public enterprises that have been audited by other than four major audit firms, that received an audit report other than a positive opinion in the previous year, and that are financially troubled and highly indebted, are more likely to switch to independent audit firms as a result of the voluntary rotation.

\section{Conclusion}

This study, investigated the factors affecting voluntary independent audit firm rotation, is selected to determine the factors that influence the rotation of volunteers registered company change the result of the audit firm in Turkey's BIST.In the study, 8 variables, which was considered that the independent audit firm changes in public companies as a result of voluntary rotation, such as previous audit opinion (PAO), size of audit firm (SAF), the financial condition of the company (FCC), size of business (SB), change of chairman (CC), business merge (BM), independence of business management (IBM) and effect of lenders (EL) were identified. 
Binary logistic regression analysis was applied to the data of these variables by using the "enter method". As a result of the analysis, it has been found that the size of business (SB), change of chairman (CC), business merge $(\mathrm{BM})$, independence of business management (IBM) variables do not make a statistically significant difference in the way public companies change independent audit firms, whereas it has been observed that the variables such as previous audit opinion (PAO), size of audit firm (SAF), the financial condition of the company (FCC) and effect of lenders (EL) are effective on independent audit firm changes.

In this case, as a result, in Turkey's BIST index traded companies, as a result of the voluntary rotation, factors affecting audit firm changes were determined such as the previous audit opinion, size of audit firm, financial condition of the company and effect of the lender. In other words, it has been concluded that public companies, which were audited by those other than four major audit firms, received an audit report other than positive opinion, financially troubled and highly indebted, were more likely to change their independent audit firm as a result of voluntary rotation.

\section{References}

Al-Khoury, A. F., Ali, A., Al-Sharif, M., Hanania, J., Al-Malki, I., and Jallad, M. (2015). "Auditor independence and mandatory auditor rotation in Jordan", International Business Research, Vol. 8, No. 4, p.73-82.

Asthana, S., Balsam S. and Kim S. (2004). "The effect of Enron, Andersen, and Sarbanes-Oxley on the market for audit services", Working Paper, June.

Bagherpour, M. A. (2007). Investigating the Factors Associated with Auditor Switches in Iran. Unpublisehd manuscript, Australian National University, Canberra, Australia.

Bagherpour, M., Monroe, G. S., and Shailer, G. (2009). Auditor Switching in an Increasingly Competitive Audit Market. Unpublished paper.

Black, E. L., Burton, F. G. and Maggina, A. (2012). "Auditor switching in the economic crisis: The case of Greece", world-finance-conference.com/papers_wfc2/279.

Black, E. L., Burton, F. G. And Maggina, A. G. (2013). "Auditor Switcing in the Economic Crisis: The Case in Greece", International Journal of Accounting and Economic Studies, Vol:1, No:2, p.39-46.

Boon, K., McKinnon, J., and Ross, P. (2007). Factors Associated with the Choice of a Quality Auditor when Audit Tendering is Compulsory. Accounting and Business Research, 31(2), p.133-144.

Branson, J., and Breesch, D. (2004). Referral as a determining factor for changing auditors in the Belgian auditing market: An empirical study. The International Journal of Accounting, 39, p.307-326.

Calderon, T. G. and Ofobike, E. (2008). Determinants of client-initiated and auditor-initiated auditor changes. Managerial Auditing Journal, 23(1), p.4-25.

Carcello, J. V. and Neal, T. L. (2003). Audit Committee Characteristics and Auditor Dismissals following New Going-Concern Reports. The Accounting Review, 78, p.95-117.

Chadegani, A. A., Mohamed, Z. M. And Jari, A. (2011). "The Determinant Factors of Auditor Switch among Companies Listed on Tehran Stock Exchange', International Research Journal of Finance and Economics, Vol:80, p.158-168.

Chen, C. L., Chang F. H. and Yen G. (2008). "The information contents of auditor change infinancial distress prediction-empirical findings from the TALEX-listed firms", Draft of paper retrieved from www.google.com, at January 12.

Cheng, W. T. (2014). "Determinants affecting auditor switching: A Malaysian study", A research submitted in partial fulfillment of the requirement for the degree of Bachelor of Commerce (Hons) Accounting, UniversitiTunku Abdu Rahman, Faculty of Business and Finance.

Dhaliwal, D. S., Gleason, C. A., Heitzman, S., Melendrez, K. D. (2007), “Audit Fees and Cost of Debt', Journal of Accounting, Auditing and Finance, 23(1) p.1-22.

Eldridge, S., Kwak, W., Venkatesh, R., Shi, Y. And Kou, G. (2012). "Predicting Auditor Changes with Financial Distress Variables: Discriminant Analysis and Problems with Data Mining Approaches", The Journal of Applied Business Reserach, Vol:28, No:6, p.1357-1372.

Eshagniya, A., Salehi, M. (2017). "The Impact of Financial Restatement on Auditor Changes: Iranian Evidence", Asia Pacific Journal of Innovation and Entrepreneurship, Vol. 11, No. 3, p. 366-390.

Ettredge, M. L., Li, C., Scholz, S. (2007). "Audit Fees and Auditor Dismissals in the Sarbanes-Oxley Era", Accounting Horizons, Vol: 21, No:4, p.371-386.

Fontain, R. and Letaifa S. B. (2012). "The reasons clients change audit firms and the client's perceived value of the audit service: A qualitative study", Unpublished Manuscript, University du Quebec a Montreal.

Han, J. and Camber, M. (2013). Data Mining Concepts and Techniques, Morgan Kaufman, San Diego, USA.

Hamilton, J., Lib, Y., and Stokes, D. (2008). Is the audit services market competitive following Arthur Andersen's collapse? Accounting and Finance, 48, p.233-258.

Haskins, M. E. and Williams, D. D. (1990). A contingent model of intra-big eight auditor changes, Auditing: A Journal of Practice and Theory, Vol:9, No:3, p.55-75. 
Huang, Y. and Scholz, S. (2012). "Evidence of the association between financial restatement andauditor resignations", Accounting Horizon, Vol. 26, No. 3, p.439-464.

Hudaib, M. And Cooke, T. E. (2005). "The Impact of Managing Director Changes and Financial Distrees on Audit Oualification and Auditor Switching”, Journal of Business Finance and Accounting, Vol. 32, No. 9-10, p. 1073-1739.

Ismail, S. H., Aliahmed H., Nassir, A., Hamid, M. A. (2008), "Why Malaysian second board companies switch auditors: Evidence of Bursa Malaysia", International Research Journal of Finance and Economics, Issue 13, p.123-130.

Jackson, A. B., Moldrich, M., and Roebuck, P. (2008). Mandatory audit firm rotation and audit quality. Managerial Auditing Journal, 23(5), p.420-437.

Kızılgöl, Ö. veİşgüden, B. (2007). "HalefveSelefDenetçilerArasındakiİletişim”, Akademik Fener, Sayı:8.

Knechel, W. R., Naiker, V. And Pacheco, G. (2007). Does Auditor Industry Specialization Matter? Evidence from Market Reaction to Auditor Switches. Auditing: A Journal of Practice and Theory, Vol:26, No:1, p.19-45.

Knechel, R. W., Niemi, L., and Sundgren, S. (2008). Determinants of Auditor Choice: Evidence from a small client market. International Journal of Auditing, 12, p.65-88.

Kwak, W., Eldridge, S., Shi, Y. And Kou, G. (2011), "Predicting Auditor Changes Using Financial Distress Variables and the Multiple Criteria Linear Programming (MCLP) and other Data Mining Approaches", The Journal of Applied Business Research, Vol:27, No:5, p.73-84.

Landsman, W. R., Nelson, K. K. And Rountree, B. R. (2009). "Auditor Switches in the Pre-and Post-Enron Eras: Risk or Realignment?", The Accounting Review, Vol:84, No:2, p.531-560.

Lennox, C. (2000). Do companies successfully engage in opinion-shopping? Evidence from UK. Journal of Accounting and Economics, 29, p.321-337.

Lin, Z. J. And Liu, M. (2010). "The determinants of auditor switching from the perspective of corporate governance in China", Advances in Accounting, incorporating Advances in International Accounting, Vol:26, No:1, p.117-127.

Ming, L. (2007). Corporate Governance, Auditor Choice and Auditor Switch: Evidence from China. Unpublished master's thesis, Hong Kong Baptist University, Hong Kong.

Nasser, A. T., Wahid, E. A., Nazri, S. N. And Hudaib, M. (2006). "Auditor Client Relationship: The Case of Audit Tenure and Auditor Switching in Malaysia”, Managerial Auditing Journal, Vol:21, No:7, p.724-737.

Nazri, S. N., Smith, M., Ismail, Z. (2012). Factors influencing auditor change: Evidence from Malaysia, Asian Review of Accounting, 20 (3), p.22-44.

Nyakuwanika, M. (2014). "Why companies change auditors in Zimbabwe?", Research Journal of Finance and Accounting, Vol. 5, No. 5, p.171-181.

Saygılı, E. E. (2011). Nansal Bilginin Güvenilirliğiileİlgili Bağımsız Denetimin Amacıve Bağımsız Denetim Süreciilellgili Son Gelişmeler, Journal of Yaşar University, 23(6), s. 3890-3903.

Sriram, R. S. (2006). "Changing auditors and the influence of client specific attributes: An analysis", The Journal of Applied Business Research, Vol. 6, No. 4, p.104-108.

Suyono, E., Feng, Y. and Riswan, M. (2013). "Determinants factors affecting the auditor switching: An Indonesian case", Global Review of Accounting and Finance, Vol. 4, No. 2, September, p.103-116.

Wan Mohamed, W. A., Hussain. W. S., MohdRodzi. N. K. (2007). Characteristics' of companies that change and do not change and do notchange auditor-an empirical investigation of Malaysian public listedcompanies. Unpublished manuscript, University of Teknology MARA, Shah Alam, Malaysia.

Weiner, J. (2012). "Auditor size vs. Auditor quality: An analysis of auditor switches", ThesisofHonors College, University of Houston.www.albany.edu/honorscollege/files/weiner_Thesis.

Woo, E. S. and Koh, H. C. (2001). Factors associated with auditor changes: a Singapore study. Accounting and Business Research, 31 (2), p.133-144.

Vanstraelen, A. (2000). Going-Concern Opinions, Auditor Switching, and the Self-Fulfiiling Prophecy Effect Examined in the Regulatory Context of Belgium. Journal of Accounting, p.231-235.

Yaman, Z., Wen, C., and Jinzheng (2013). "Auditor switching by corporate governance: Empirical analysis from the listed company in China", Journal of Modern Accounting and Auditing, Vol. 9, No. 2, p.230-238.

Yaşar, A. (2016). Bă̆ımsızDenetimKuruluşuDeğişiklikleriniEtkileyenFaktörlerinBelirlenmesiÜzerineBirAraş̧ırma, AkademisyenKitabevi, SonçağMatbaacılık, Ankara. 